\title{
Cyclobacterium lianum sp. nov., a marine bacterium isolated from sediment of an oilfield in the South China Sea, and emended description of the genus Cyclobacterium
}

\author{
Jiao-Yan Ying, ${ }^{1,2}$ Bao-Jun Wang, ${ }^{2}$ Su-Sheng Yang ${ }^{1}$ \\ and Shuang-Jiang Liu \\ ${ }^{1}$ College of Biological Sciences, China Agricultural University, Beijing 100094, People's \\ Republic of China \\ ${ }^{2}$ State Key Laboratory of Microbial Resources, Institute of Microbiology, Chinese Academy of \\ Sciences, ZhongGuanCun, Haidian, Beijing 100080, People's Republic of China
}

Correspondence

Shuang-Jiang Liu liusj@sun.im.ac.cn
Many members of the phylum Bacteroidetes (or CytophagaFlavobacterium-Bacteroides) are involved in biogeochemical cycles in aquatic environments (Bowman et al., 2003; and references therein). For instance, members of the genus Cyclobacterium displaying the unique ring-like and horseshoe-shaped morphology are common constituents of marine environments. At the time of writing, the genus Cyclobacterium (Raj \& Maloy, 1990) contains two species with validly published names: Cyclobacterium marinum, isolated from the deep sea in the Gulf of California (Raj \& Maloy, 1990; Euzéby, 1998), and Cyclobacterium amurskyense, isolated from water in the Sea of Japan (Nedashkovskaya et al., 2005). Organisms sharing high levels of 16S rRNA gene sequence similarity with Cyclobacterium species have also been found in salt-marsh sediment (GenBank accession no. AY259502) and a soda lake (AF275712). In this study, we describe a rose-pigmented bacterial strain with ring-like and horseshoe-shaped cells,

The GenBank/EMBL/DDBJ accession number for the 16S rRNA gene sequence of strain $\mathrm{HY}^{\top}$ is D0534063.

A transmission electron micrograph of strain $\mathrm{HY}^{\top}$, two phylogenetic trees and a table of fatty acid compositions are available as supplementary material in IJSEM Online. designated strain $\mathrm{HY9}^{\mathrm{T}}$ and isolated from sediment of the South China Sea. A polyphasic analysis of strain $\mathrm{HY}^{\mathrm{T}}$ indicated that the isolate represents a novel species of the genus Cyclobacterium.

Strain $\mathrm{HY}^{\mathrm{T}}$ was isolated from sediment of the Xijiang oilfield in the South China Sea, near Fujian Province, China; sampling was performed at a depth of about $100 \mathrm{~m}$. For isolation, serially diluted sediment samples were spread onto low-organic marine agar 2216 plates [containing $0.5 \mathrm{~g}$ peptone $l^{-1}$ and $0 \cdot 1$ g yeast extract $l^{-1}$; the salt composition and concentration were the same as in marine agar 2216 (MA; Difco)] and incubated at $30^{\circ} \mathrm{C}$ for 10 days. A colony of $\mathrm{HY}^{\mathrm{T}}$ was collected and subcultured on MA. The temperature and $\mathrm{pH}$ ranges for growth, the tolerance of $\mathrm{NaCl}$ and the substrates used as sole carbon sources were determined according to the methods described by Cho \& Giovannoni (2003). Strain $\mathrm{HY}^{\mathrm{T}}$ was tested on API ZYM (bioMérieux) and Biolog GN2 MicroPlate systems, according to the manufacturers' instructions. All other biochemical tests were performed according to Dong \& Cai (2001). Susceptibility to antibiotics was determined using filterpaper discs containing various antibiotics, as specified in the species description. The morphology of cells grown on MA 
Table 1. Differential properties of strain $\mathrm{HYg}^{\top}$ and the type strains of C. marinum and C. amurskyense

Strains: $1, \mathrm{HY}^{\mathrm{T}}$; 2, C. marinum LMG $13164^{\mathrm{T}}$; 3, C. amurskyense KMM $6143^{\mathrm{T}}$. Data are from Nedashkovskaya et al. (2005) and this study.

\begin{tabular}{|lccc|}
\hline Characteristic & $\mathbf{1}$ & $\mathbf{2}$ & $\mathbf{3}$ \\
\hline Lipase & - & - & + \\
Trypsin & - & - & + \\
Growth at $42{ }^{\circ} \mathrm{C}$ & + & + & - \\
Acid production from: & & & \\
$\quad$ Glucose & + & - & - \\
L-Arabinose & + & - & + \\
DL-Xylose & + & - & + \\
Starch & - & - & + \\
Utilization of: & & & \\
D-Gluconate & + & - & + \\
L-Fucose & - & + & + \\
L-Sorbose & - & + & + \\
Hydrolysis of Tween 20 & + & - & - \\
Susceptibility to: & & & \\
Benzyl penicillin & + & - & + \\
Kanamycin & + & - & + \\
Streptomycin & - & + & - \\
Tetracycline & - & + & - \\
DNA G+C content $(\mathrm{mol} \%)$ & $45 \cdot 2$ & $41 \cdot 9$ & $41 \cdot 3$ \\
& & & \\
\hline
\end{tabular}

for 2 days at $30{ }^{\circ} \mathrm{C}$ was studied using transmission electron microscopy (Zhang et al., 2002).

The novel isolate displayed the basic characteristics of members of the genus Cyclobacterium, e.g. the colonies were rose-pigmented and the cells were curved, ring-like or horseshoe-shaped (see Supplementary Fig. S1 available in IJSEM Online). Other phenotypic properties of strain $\mathrm{HY}^{\mathrm{T}}$ are given in the species description and in Table 1.

The almost-complete 16S rRNA gene (1485 bp) of strain $\mathrm{HY} 9^{\mathrm{T}}$ was amplified using the bacterial universal primers
27F and 1492R (Lane, 1991) and sequenced. Preliminary comparisons with sequences held in GenBank, performed using BLASTN searches, revealed that the isolate was related to C. marinum. Further analysis of $16 \mathrm{~S}$ rRNA gene sequences was performed using MEGA, version 3.1 (Kumar et al., 2004). Strain $\mathrm{HY9}^{\mathrm{T}}$ showed highest sequence similarity with $C$. marinum DSM $745^{\mathrm{T}}(93.6 \%)$ and C. amurskyense KMM $6143^{\mathrm{T}}(92 \cdot 8 \%)$, followed by members of the genera Aquiflexum (89.7\%), Belliella (89.7\%), Hongiella $(87 \cdot 8-90 \cdot 3 \%)$, Chimaereicella $(88 \cdot 4 \%)$ and Algoriphagus $(88 \cdot 3-89 \cdot 5 \%)$. Phylogenetic trees were constructed with MEGA, version 3.1, using the neighbour-joining method (Saitou \& Nei, 1987), maximum parsimony (Fitch, 1971) and minimum evolution (Felsenstein, 1997). The resulting tree topology was evaluated using the Kimura twoparameter calculation model (Kumar et al., 2004) based on 1000 replicates. As shown in Fig. 1 and Supplementary Fig. S2 (available in IJSEM Online), strain $\mathrm{HY9} 9^{\mathrm{T}}$ formed a monophyletic clade with $C$. marinum and C. amurskyense. The closest relatives of this clade were members of the genera Aquiflexum and Belliella (Brettar et al., 2004a, b).

The whole-cell fatty acid composition was determined from cells cultured at $30^{\circ} \mathrm{C}$ on MA for 2 days. The cellular fatty acids were extracted, methylated and analysed by using the Sherlock Microbial Identification System (MIDI) according to the manufacturer's instructions. The major cellular fatty acids were iso- $\mathrm{C}_{15: 0}(28 \cdot 3 \%)$, summed feature 3 (iso- $\mathrm{C}_{15: 0}$ $2-\mathrm{OH}$ and/or $\left.\mathrm{C}_{16: 1} \omega 7 c ; 16 \cdot 6 \%\right)$, iso- $\mathrm{C}_{17: 1} \omega 9 c(10 \cdot 3 \%)$, iso- $\mathrm{C}_{17: 0} 3-\mathrm{OH}(8 \cdot 0 \%)$ and anteiso- $\mathrm{C}_{15: 0}(6 \cdot 4 \%)$, similar to the profiles reported for C. marinum and C. amurskyense (Nedashkovskaya et al., 2005). The complete fatty acid composition of strain $\mathrm{HY}^{\mathrm{T}}$ is given in Supplementary Table S1 (available in IJSEM Online). The G $+C$ content of the DNA was determined by thermal denaturation (Marmur \& Doty, 1962; Seidler \& Mandel, 1971) using DNA from Escherichia coli $\mathrm{K}-12$ as a control. The G $+\mathrm{C}$ content of strain $\mathrm{HY}^{\mathrm{T}}$ was $45 \cdot 2 \mathrm{~mol} \%$, which is slightly higher than those of the type strains of C. marinum $(41.9 \mathrm{~mol} \%)$ and $C$. amurskyense (41.3 mol\%) (Nedashkovskaya et al., 2005).

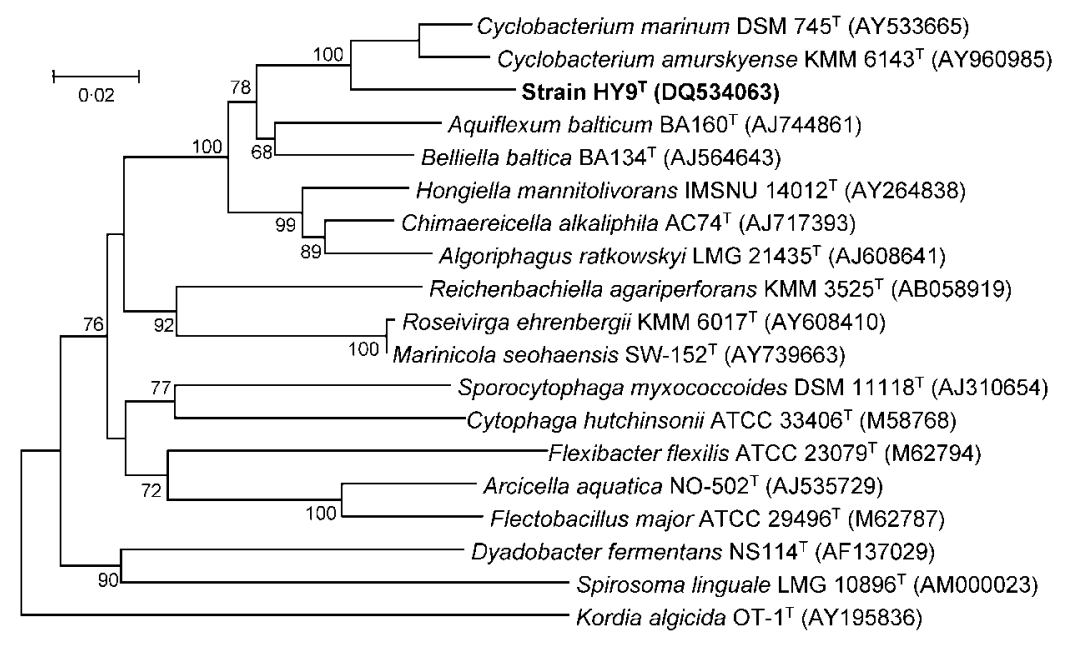

Fig. 1. Neighbour-joining tree based on comparisons of the 16S rRNA gene sequences of strain $\mathrm{HY}^{\top}$ and related members of the family 'Flexibacteraceae'. Bootstrap values (expressed as percentages of 1000 replicates) greater than $50 \%$ are shown at branching points. Bar, 0.02 substitutions per nucleotide position. 
On the basis of these results, we concluded that strain $\mathrm{HY}^{\mathrm{T}}$ represents a novel species within the genus Cyclobacterium, for which the name Cyclobacterium lianum sp. nov. is proposed. The properties that serve to differentiate strain $\mathrm{HY}^{\mathrm{T}}$, C. marinum and C. amurskyense from each other are listed in Table 1. As some of the properties of C. lianum (from this study) and C. amurskyense (Nedashkovskaya et al., 2005) were not included in or are not compatible with the original description of the genus Cyclobacterium (Raj \& Maloy, 1990), an emended description of the genus is also proposed.

\section{Description of Cyclobacterium lianum sp. nov.}

Cyclobacterium lianum (N.L. neut. adj. lianum pertaining to $\mathrm{Li}$, named in honour of Professor Ji-Lun Li, who devotes himself to microbiological research and education in China).

Cells are Gram-negative, aerobic and heterotrophic, nonmotile, curved, ring-like or horseshoe-shaped, $0 \cdot 4-0 \cdot 5 \mu \mathrm{m}$ wide, and the outer diameter of rings is $1.5-1 \cdot 8 \mu \mathrm{m}$. Colonies grown for 3 days on MA are circular $(2-3 \mathrm{~mm}$ in diameter), light rose in colour and shiny. Growth occurs at $15-42{ }^{\circ} \mathrm{C}$ (optimum $33^{\circ} \mathrm{C}$ ), at $\mathrm{pH} 6 \cdot 5-9 \cdot 0$ (optimum pH 7.5-8.0) and with $0 \cdot 1-12 \% \mathrm{NaCl}$ (optimum 1-4\%). Positive for oxidase and catalase activities, but negative for arginine dihydrolase, urease and lecithinase activities. Indole and $\mathrm{H}_{2} \mathrm{~S}$ are not produced and nitrate is not reduced. Aesculin and Tween 20 are hydrolysed. Tweens 40 and 80 are hydrolysed weakly; agar, casein, gelatin, starch, DNA and carboxymethyl-cellulose are not hydrolysed. Glucose, sucrose, D-melibiose, ribose, lactose, galactose, maltose, melezitose, inulin, L-rhamnose, L-arabinose, D-raffinose, trehalose, cellobiose, methyl $\alpha$-D-glucoside and gluconate are utilized as sole carbon sources. Glycerol, mannitol, Dmannose, D-fructose, D-xylose, lactic acid, succinate, malate, pyruvate and L-glutamic acid are weakly utilized. L-Fucose, L-sorbose, dulcitol, adonitol, myo-inositol, citrate, malonate, L-lysine, L-alanine, formic acid, butyric acid and caprate are not utilized. Forms acid from glucose, ribose (weakly), sucrose, D-melibiose, lactose, galactose, maltose, melezitose, inulin, L-rhamnose, L-arabinose, D-raffinose, trehalose, cellobiose, D-xylose, glycerol (weakly) and methyl $\alpha$-D-glucoside. Shows strong activity in the API ZYM system for alkaline and acid phosphatases, leucine and valine arylamidases, naphthol-AS-BI-phosphohydrolase, $\beta$ galactosidase, $\alpha$ - and $\beta$-glucosidases and $N$-acetyl- $\beta$-glucosaminidase. Shows weak activity for esterases C4 and C8, cystine arylamidase, $\alpha$-galactosidase and $\alpha$-mannosidase. No activity is shown for trypsin, $\alpha$-chymotrypsin, $\beta$-glucuronidase, $\alpha$-fucosidase or lipase (C14). In GN2 MicroPlates, dextrin, $N$-acetyl-D-glucosamine, L-arabinose, D-cellobiose, $\mathrm{D}$-fructose, D-galactose, gentiobiose, $\alpha$-D-glucose, $\alpha$-Dlactose, lactulose, maltose, D-mannose, D-melibiose, methyl $\beta$-D-glucoside, D-raffinose, sucrose, D-trehalose, turanose, D-galacturonic acid, DL-lactic acid, glucuronamide, L-alaninamide, L-alanine, DL-carnitine, 2,3-butanediol, glycerol, DL- $\alpha$-glycerol phosphate and glucose 1-phosphate are oxidized. Weak or variable results are detected with glycogen, $\mathrm{N}$-acetyl-D-galactosamine, i-erythritol, D-mannitol, D-psicose, L-rhamnose, D-sorbitol, monomethyl succinate, D-gluconic acid, $\alpha$-ketovaleric acid, succinic acid, L-alanyl glycine, L-asparagine, L-aspartic acid, glutamic acid, L-ornithine, L-proline, L-pyroglutamic acid, DL-serine, L-threonine, $\gamma$-aminobutyric acid, uridine, 2-aminoethanol and glucose 6-phosphate. Resistant to the following antibiotics $(\mu \mathrm{g})$ : gentamicin (10), neomycin (30), polymyxin B (300), streptomycin (10) and tetracycline (30). Sensitive to the following antibiotics $(\mu \mathrm{g})$ : ampicillin (10), carbenicillin (100), vancomycin (30), ciprofloxacin (5), rifampicin (5), norfloxacin (10), chloramphenicol (30), benzyl penicillin (10), kanamycin (30) and erythromycin (15). The major cellular fatty acids $(>5 \%)$ are iso- $\mathrm{C}_{15: 0}$ $\left(28 \cdot 3 \%\right.$ ), summed feature 3 (iso- $\mathrm{C}_{15: 0} 2-\mathrm{OH}$ and/or $\left.\mathrm{C}_{16: 1} \omega 7 c ; 16 \cdot 6 \%\right)$, iso- $\mathrm{C}_{17: 1} \omega 9 c(10 \cdot 3 \%)$, iso- $\mathrm{C}_{17: 0} 3-\mathrm{OH}$ $(8 \cdot 0 \%)$ and anteiso- $\mathrm{C}_{15: 0}(6 \cdot 4 \%)$. The molar $\mathrm{G}+\mathrm{C}$ content of the DNA is $45 \cdot 2 \mathrm{~mol} \%$.

The type strain, HY9 ${ }^{\mathrm{T}}\left(=\mathrm{CGMCC} 1.6102^{\mathrm{T}}=\mathrm{JCM} 14011^{\mathrm{T}}\right)$, was isolated from sediment from the Xijiang oilfield in the South China Sea.

\section{Emended description of the genus Cyclobacterium}

Colonies on MA are pink-pigmented and shiny. Cells are curved, ring-like or horseshoe-shaped. Neutrophilic and mesophilic. Optimal growth temperature range is $25-30{ }^{\circ} \mathrm{C}$. $\mathrm{NaCl}$ is required for growth. The major cellular fatty acids are iso- $\mathrm{C}_{15: 0}$, summed feature 3 (iso- $\mathrm{C}_{15: 0} 2-\mathrm{OH}$ and/or $\mathrm{C}_{16: 1} \omega 7 c$ ), iso- $\mathrm{C}_{17: 1} \omega 9 c$, iso- $\mathrm{C}_{17: 0} 3-\mathrm{OH}$ and anteiso- $\mathrm{C}_{15: 0}$. The DNA G + C content is $41-45 \mathrm{~mol} \%$.

\section{Acknowledgements}

This work was supported by grants from the National Natural Science Foundation of China (30230010).

\section{References}

Bowman, J. P., Nichols, C. M. \& Gibson, J. A. E. (2003). Algoriphagus ratkowskyi gen. nov., sp. nov., Brumimicrobium glaciale gen. nov., sp. nov., Cryomorpha ignava gen. nov., sp. nov. and Crocinitomix catalasitica gen. nov., sp. nov., novel flavobacteria isolated from various polar habitats. Int J Syst Evol Microbiol 53, 1343-1355.

Brettar, I., Christen, R. \& Höfle, M. G. (2004a). Belliella baltica gen. nov., sp. nov., a novel marine bacterium of the CytophagaFlavobacterium-Bacteroides group isolated from surface water of the central Baltic Sea. Int J Syst Evol Microbiol 54, 65-70.

Brettar, I., Christen, R. \& Höfle, M. G. (2004b). Aquiflexum balticum gen. nov., sp. nov., a novel marine bacterium of the CytophagaFlavobacterium-Bacteroides group isolated from surface water of the central Baltic Sea. Int J Syst Evol Microbiol 54, 2335-2341.

Cho, J. C. \& Giovannoni, S. J. (2003). Parvularcula bermudensis gen. nov., sp. nov., a marine bacterium that forms a deep branch in the $\alpha$ Proteobacteria. Int J Syst Evol Microbiol 53, 1031-1036.

Dong, X.-Z. \& Cai, M.-Y. (2001). Determinative Manual for Routine Bacteriology. Beijing: Scientific Press. 
Euzéby, J. P. (1998). Taxonomic note: necessary correction of specific and subspecific epithets according to Rules $12 \mathrm{c}$ and $13 \mathrm{~b}$ of the International Code of Nomenclature of Bacteria (1990 Revision). Int J Syst Bacteriol 48, 1073-1075.

Felsenstein, J. (1997). An alternative least-squares approach to inferring phylogenies from pairwise distances. Syst Biol 46, 101-111.

Fitch, W. M. (1971). Toward defining the course of evolution: minimum changes for a specific tree topology. Syst Zool 20, 406-416.

Kumar, S., Tamura, K. \& Nei, M. (2004). MEGA3: integrated software for molecular evolutionary genetics analysis and sequence alignment. Brief Bioinform 5, 150-163.

Lane, D. J. (1991). 16S/23S rRNA sequencing. In Nucleic Acid Techniques in Bacterial Systematics, pp. 115-175. Edited by E. Stackebrandt \& M. Goodfellow. Chichester: Wiley.

Marmur, J. \& Doty, P. (1962). Determination of the base composition of deoxyribonucleic acid from thermal denaturation temperature. J Mol Biol 5, 109-118.
Nedashkovskaya, O. L., Kim, S. B., Lee, M. S., Park, M. S., Lee, K. H., Lysenko, A. M., Oh, H. W., Mikhailov, V. V. \& Bae, K. S. (2005). Cyclobacterium amurskyense sp. nov., a novel marine bacterium isolated from sea water. Int J Syst Evol Microbiol 55, 2391-2394.

Raj, H. D. \& Maloy, S. R. (1990). Proposal of Cyclobacterium marinum gen. nov., comb. nov. for a marine bacterium previously assigned to the genus Flectobacillus. Int J Syst Bacteriol 40, 337-347.

Saitou, N. \& Nei, M. (1987). The neighbor-joining method: a new method for reconstructing phylogenetic trees. Mol Biol Evol 4, 406-425.

Seidler, R. J. \& Mandel, M. (1971). Quantitative aspects of deoxyribonucleic acid renaturation: base composition, state of chromosome replication, and polynucleotide homologies. J Bacteriol 106, 608-614.

Zhang, D., Yang, H., Huang, Z., Zhang, W. \& Liu, S.-J. (2002). Rhodopseudomonas faecalis sp. nov., a phototrophic bacterium isolated from an anaerobic reactor that digests chicken faeces. Int J Syst Evol Microbiol 52, 2055-2060. 